\title{
Sinterability and Microstructure Evolution During Sintering of Ferrous Powder Mixtures
}

\author{
Kétner Bendo Demétrio ${ }^{\mathrm{a}, b *}$, Aloisio Nelmo Klein ${ }^{\mathrm{a}}$, Lirio Schaeffer ${ }^{\mathrm{b}}$, Deise Rebelo Consonic,
} Antonio Eduardo Martinelli ${ }^{\text {d Tatiana Bendo }}{ }^{\mathrm{a}}$

\author{
a'Departamento de Engenharia Mecânica, Laboratório de Materiais, Universidade Federal de \\ Santa Catarina - UFSC, CEP 88040-900, Florianópolis, SC, Brazil \\ ${ }^{\mathrm{b}}$ Laboratório de Tranformação Mecânica, Universidade Federal do Rio Grande do Sul - UFRGS, \\ CEP 91501-970, Porto Alegre, RS, Brazil \\ ${ }^{\circ}$ Laboratório de Microscopia Eletrônica, Universidade Federal de Santa Catarina - UFSC, \\ CEP 88040-900, Florianópolis, SC, Brazil \\ ${ }^{\mathrm{d}}$ Departamento de Engenharia de Materiais, Laboratório de Cimentos, Universidade Federal do \\ Rio Grande do Norte - UFRN, CEP 59078-970, Natal, RN, Brazil
}

Received: September 12, 2012; Revised: February 13, 2013

\begin{abstract}
The present work is focused on ferrous powder metallurgy and presents some results of a development of a suitable masteralloy for use as an additive to iron powder for the production of sintered steels. The masteralloy was produced by melting a powder mixture containing approximately $\mathrm{Fe}+20 \% \mathrm{Ni}+20 \% \mathrm{Mn}+20 \% \mathrm{Si}+1 \% \mathrm{C}$ (wt $\%$ ), in order to obtain a cast billet that was converted into fine powder by crushing and milling. It was observed presence of $\mathrm{SiC}$ in the masteralloy after melting that is undesirable in the alloy. Si element should be introduced by using ferrosilicon. Sintered alloys with distinct contents of alloying elements were prepared by mixing the masteralloy powder to plain iron powder. Samples were produced by die compaction of the powder mixtures and sintering at $1200{ }^{\circ} \mathrm{C}$ in a differential dilatometer in order to record their linear dimensional behaviour during heating up and isothermal sintering, aiming at studying the sinterability of the compacts. Microstructure development during sintering was studied by SEM, XRD and microprobe analyses.
\end{abstract}

Keywords: ferrous powder metallurgy, alloying techniques, masteralloy

\section{Introduction}

As a result of the current advanced stage of technological development, materials with particular properties designed especially for each specific application are required. In this scenario, sintered materials are getting more importance due to the fact that the microstructure of these materials can be easily controlled and tailored specifically for each particular engineering function or application. In this way, technologies of processing materials from powders have experienced growing economic and technological importance in recent decades ${ }^{1-3}$.

Sintered materials are produced from ceramic and metallic powders, as well as from mixtures of both. Various distinct shaping techniques are in use for the consolidation of the powders (or powder feedstock's) in finished sintered parts. Due to economic reasons, the currently most used ones are axial die pressing (powder compaction) ${ }^{4,5}$ and powder injection molding ${ }^{6-8}$.

The choice depends on a series of aspects including shape complexity of the part, quality needed for the final material (properties), and characteristics of available powders for feedstock preparation, among others. For the preparation of the final chemical composition of the sintered material starting from powders, two distinct ways are possible:

- Processing of pre-alloyed powders ${ }^{9}$, i.e, powders in which each particle has the final composition of

*e-mail: ketnerbd@gmail.com the material. In this case, the specific powders with the desired final chemical composition have to be available. Their production is normally expensive, especially in the case of metallic alloy powders. Furthermore, the compressibility of the pre-alloyed metallic powders is very low as a result of the hardening effects of alloying elements in the powder particle composition, resulting in low green densities of the compacted parts. Sintering low green density parts often results in high shrinkage, which negatively affects the control of the dimensional quality of the sintered parts. As a result, complementary calibration or machining operations are necessary, thus increasing the production costs. Pre-alloyed powders are largely used for powder metallurgy as surface densified gears (using Fe-Mo) or synchronizer hubs (using Fe-Cr-Mo) used in automotive transmissions ${ }^{10}$;

- Processing of powder blends, i.e, powder feedstock produced by mixing distinct powdered components (elemental powders, compounds or phases) of the material. In this case, reactions may occur between the several distinct phases or components present in the powder mixture during sintering, at towards the thermodynamic equilibrium of the system. The reactions between the powder particles of the distinct powdered raw materials (elemental powders of the chemical elements, compound powders or other phases) results in the formation of new phases and/or 
compounds at the expense of existing ones, according to the thermodynamic equilibrium of each particular system. Accordingly, microstructure formation gradually goes through a sequence of transient states towards equilibrium. The stage where sintering has to be interrupted depends on the particular engineering function that the sintered parts has to provide under service conditions. This means that sintering has to be interrupted at the right time in order to maintain the microstructure and phase composition desired in the sintered material.

Steels are the mostly used sintered metallic materials. In spite of the fact that ferrous powder metallurgy products, i.e, parts made from sintered steels, are often used as a consequence of their good mechanical properties and surface finishing, in most of the cases their use results from low production costs. Therefore, additional costs related to the development of new sintered steels and components are normally not welcome. For the production of sintered steel parts, pre-alloyed powders are used only in special cases, such as stainless steel parts or high-speed steels. The most common way is to produce parts from powder mixtures of the elemental powders. An interesting possibility is to mix a powder of a specific alloy-carrier, namely masteralloy, in which the desired alloying elements are present in suitable concentrations. The masteralloy powder is mixed with plain iron as an additive and the desired steel is formed in situ during sintering via diffusion homogenization. Several studies in which specific masteralloys were produced and added as fine powders to plain iron powder for the preparation of sintered steels have been reported elsewhere ${ }^{1-3,10-17}$. Typical alloys produced by masteralloy technique are MCM (Mo-Cr-Mn), MVM (Mo-V-Mn) ${ }^{16-19}$ and SM (Fe-Si-Mn) ${ }^{13}$.

In conventional powder metallurgy steels $\mathrm{Cu}$, Mo and $\mathrm{Ni}$ are common alloying elements due to their good mechanical properties and low oxygen affinity are obtained in the sintered steels made from partially diffusion alloyed $\mathrm{Fe}-\mathrm{Cu}-\mathrm{Mo}-\mathrm{Ni}$ powders ${ }^{14,20-23}$.

It is also well known that sinterability and microstructure formation during sintering of the compact are strongly affected by the particular alloying technique used for alloying the matrix ${ }^{1-3,13,15}$. This is specially the case when the alloy is prepared by mixing elemental powders and powders of compounds that are able to mutually react. Furthermore, some elements with metallurgical advantages to the steel properties, e.g., V, Si, Mn, $\mathrm{Cr}$ and $\mathrm{Ti}$ are difficult to be protected against oxidation during sintering under industrial conditions, as a result of their high affinity for oxygen ${ }^{12,15}$.

In this case, highly pure sintering atmospheres regarding the chemical potential of oxygen are necessary to avoid oxidation. In this case, the use of pre-alloyed powders can be advantageous because the alloying elements are less susceptible to oxidation once in solution in the iron matrix due to their lower chemical activity in solution. Oxidation protection can also be achieved by adding the alloying elements to the powder mixture (feedstock) in the form of compounds, such as carbides and nitrides, or in the form of binary ferroalloys such as ferrosilicon, ferromanganese and ferrochromium, or even as masteralloys ${ }^{1-3,12-14}$.

So, the present paper is part of a research subject that has the objective to develop a suitable masteralloy (multi-alloying element carrier) for use as an additive to iron powder for the production of sintered steels with high mechanical resistance than steels produced by conventional processes (e.g. foundry process).

\section{Experimental Procedure and Materials}

\subsection{Preparation of the masteralloy powder}

A masteralloy containing $\mathrm{Si}, \mathrm{Mn}, \mathrm{Ni}$ and $\mathrm{C}$ as alloying elements in high concentrations was obtained by melting a powder mixture. The masteralloy was conveniently called SMN1 (where $\mathrm{S}=\mathrm{Si} ; \mathrm{M}=\mathrm{Mn}$ and $\mathrm{N}=\mathrm{Ni}$ ). The powder mixture was prepared by mixing carbonyl iron powder (with particle size at $90 \%$ of 4-8 $\mu \mathrm{m}$ ), atomized elemental nickel powder (with mean particle size of $14 \mu \mathrm{m}$ ), silicon carbide (containing $70 \mathrm{wt} \% \mathrm{Si}$, with mean particle size of $70 \mu \mathrm{m}$ ), ferrosilicon powder (containing 45 w/o Si, with particle size at $90 \%$ of $22 \mu \mathrm{m}$ ) and ferromanganese powder (containing $64 \mathrm{wt} \% \mathrm{Mn}$, with mean particle size of $106 \mu \mathrm{m}$ ). The content of each powder was adjusted aiming at obtaining approximately the composition $\mathrm{Fe}+20 \% \mathrm{Ni}+20 \%$ $\mathrm{Mn}+20 \% \mathrm{Si}+1 \% \mathrm{C}(\mathrm{wt} \%)$ in the cast billet. To determine the percentage of each powder in the mixture, the vapour pressure of each chemical element present and its affinity to react with residual oxygen during melting was taken into account. According to the thermodynamic data, it was expected that each chemical element present in the powder mixture should be lost in distinct quantities during melting. Contents (in wt\%) of each chemical element present in the powder mixture prepared for melting is shown in Table 1. Chemical analyses were given by suppliers of powders.

The powder was mixed during 45 minutes in a Y-type mixer in order to obtain a homogeneous mixture. The powder mixture was then pressed into cylindrical samples ( $9 \mathrm{~mm}$ of diameter and $10 \mathrm{~mm}$ of height) to accelerate the reaction and melt the alloy. The pressed samples were placed in a crucible and melted in an arc furnace under inert atmosphere. After melting, the resulting cast billet was converted into fine powder by crushing and milling in a planetary mill using 8 and $10 \mathrm{~mm}$ grinding balls. The final chemical composition measured for the masteralloy after melting is presented in Table 2 . The result is the average of 2 analyses done in an external laboratory.

Laser diffraction analyses were performed to measure the particle size distribution of the SMN1 milled powder in a CILAS 1180 liquid laser diffraction. The morphology of the resulting SMN1 powder was identified by JEOL JSM6390LV Scanning Electron Microscopy (SEM). The phases present in the SMN1 powder were identified from diffraction patterns collected in a X'Pert Philips X-ray diffraction system using $\mathrm{Cu} k \alpha(=1.54 \mathrm{~A})$ source. Differential Thermal Analysis (DTA) was also carried out under argon using a heating up rate of $20^{\circ} \mathrm{C} / \mathrm{min}$ up to the melting temperature of the SMN1 powder in Netzsch 449 F3 Jupiter equipment.

\subsection{Preparation of sintered steels using the SMN1 masteralloy powder as alloying additive}

In order to study and analyse the effects on the sinterability of SMN1 as additive to plain iron matrix, powder mixtures were prepared with two distinct contents (6 and 12\% in weight) of the masteralloy powder in order to obtain around 1.5 and 2.5 (wt $\%$ ) for $\mathrm{Mn}, \mathrm{Ni}$ and $\mathrm{Si}^{13,14}$. The atomized super compressible Höganäs ASC 100.29 
was used as iron powder. Zinc stearate $(0.75 \%$ in weight) was mixed into the powder blend as lubricant. The powders were mixed for 45 minutes in a Y-type mixer. The chemical compositions of the powder blends after mixing are shown in Table 3.

Green and sintered densities were performed by $\rho=(m / V)$, where $m$ is the mass and $V$ is volume. Theoretical density was calculated by rule of mixture, in which the density of the melted masteralloy determined by Archimedes method was used. Assuming the material is free from any porosity, Archimedes density $\left(\rho_{s}\right)$ was calculated by $\rho s=(m /(m-m a))$ pwater, where $m$ is the mass of the sample, $m_{a}$ is the apparent mass and $\rho_{\text {water }}$ is the density of water. Final density was calculated by the average of 5 measurements.

For the sinterability study, cylindrical samples (diameter $=9 \mathrm{~mm}$ and height $=10 \mathrm{~mm}$ ) were uniaxially pressed parallel to the compaction direction in a steel die under 700 MPa. Delubing of the samples was undertaken in a tubular laboratory furnace under a flowing mixture of $95 \%$ Argon and $5 \%$ hydrogen, for 30 minutes at $500{ }^{\circ} \mathrm{C}$. After delubing, the samples were sintered in a Netzsch DIL 402 dilatometer which recorded the dimensional changes during heating up (rate of $\left.10{ }^{\circ} \mathrm{C} / \mathrm{min}\right)$ and isothermal sintering $\left(1200{ }^{\circ} \mathrm{C}, 60\right.$ minutes $)$ under a mixture of $\mathrm{Ar}+\mathrm{H} 2(5 \%)$ atmosphere.

In order to study the microstructure of the SMN1 cast billet and sintered steels, analyses were performed by light optical microscopy using an Olympus BX60M Optical Microscope, conventional and field emission scanning electron microscopy and using a JEOL JSM-6701F Field Emission Scanning Electron Microscope. Samples were prepared by grinding and polishing the surfaces used to reveal their microstructures subsequently etched in marble solution (for SMN1) or nital 2\% (sintered steels).

Qualitative chemical composition of the alloys was carried out using a Thermo Scientific 6733A-INES-SN Energy Dispersive Spectrometer (EDS) coupled to the SEM. Vickers microhardness was carried out in LECO LM-100AT

Table 1. Amount of chemical elements mixed for the production of the SMN1masteralloy.

\begin{tabular}{cccccc}
\hline $\begin{array}{c}\text { Chemical } \\
\text { element }\end{array}$ & Si & Mn & Ni & C & Fe \\
\hline wt. $(\%)$ & 20.14 & 21.15 & 19.23 & 1.01 & balance \\
\hline
\end{tabular}

Table 2. Chemical composition of the SMN1masteralloy powder.

\begin{tabular}{cccccc}
\hline $\begin{array}{c}\text { Chemical } \\
\text { element }\end{array}$ & Si & Mn & Ni & $\mathbf{C}$ & Fe \\
\hline wt. $(\%)$ & 20.65 & 23.40 & 20,01 & 1.05 & balance \\
\hline
\end{tabular}

Table 3. Chemical composition of sintered steels (powder mixtures).

\begin{tabular}{lccccc}
\hline \multicolumn{1}{c}{ Chemical element } & Mn & Ni & Si & C & $\begin{array}{c}\text { Fe } \\
\text { (matrix) }\end{array}$ \\
\hline $\mathrm{Fe}+6 \%$ SMN1 (wt\%) & 1.40 & 1.20 & 1.24 & 0.06 & balance \\
$\mathrm{Fe}+12 \%$ SMN1 (wt\%) & 2.80 & 2.40 & 2.48 & 0.12 & balance \\
\hline
\end{tabular}

equipment using loads from 10 to $50 \mathrm{~g}$. The average of 20 indentations was performed.

\section{Results and Discussion}

\subsection{Characterization of casted "masteralloy" material}

The microstructure of SMN1 is shown in Figure 1, where different phases can be seen. For identification of the phases further analysis with other techniques were performed.

Images from FEG electron microscope show microstructure of the molten masteralloy billet consisted of four distinct phases as well as extensive cracking, as it can be seen in Figure 2.

EDS analyses were performed in the different phases observed in the microstructure of the masteralloy SMN1. Phase 1 presents large amounts of Mn as shown the Figure 3. On the other hand, phase 2 presents much more $\mathrm{Si}$ in its composition. Phase 3 shows the presence of oxygen, Ni and $\mathrm{Si}$ and a smaller amount of Fe comparing with the other two phases (1 and 2). Silicon carbide is represented by phase 4 .

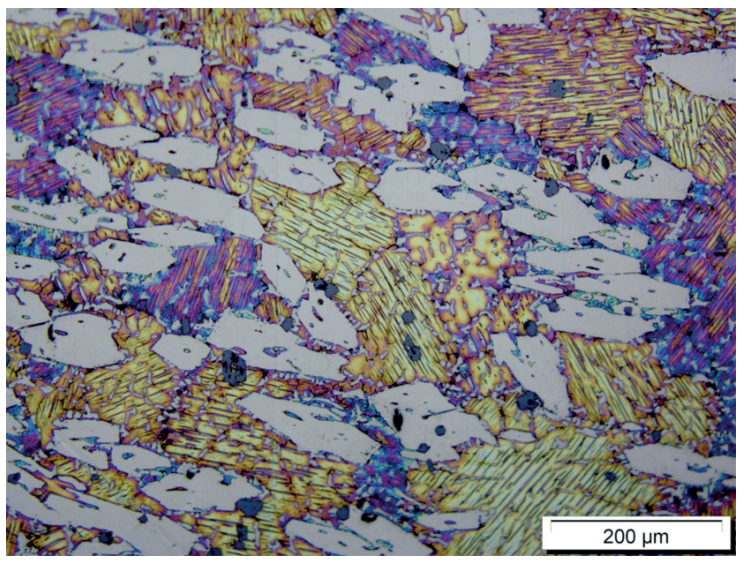

Figure 1. Optical image of the microstructure of masteralloy SMN1 after melting in arc furnace and etched in marble solution.

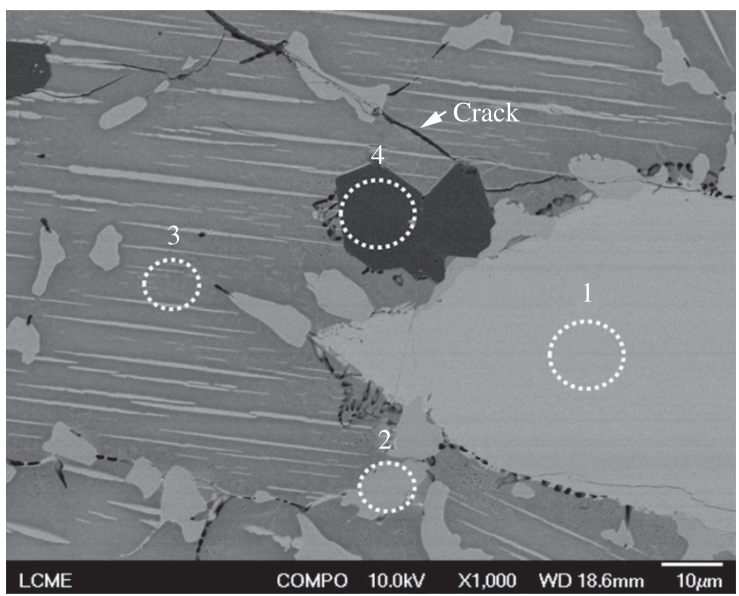

Figure 2. Image from FEG electron microscope of SMN1 sample etched in marble. All four phases are numbered in the image. 
The presence of a carbon nodule inside a SiC particle which was mixed to the powder feedstock used to melt the masteralloy is illustrated in Figure 4. Its presence suggests that $\mathrm{SiC}$ particles began to dissociate, but the process was not completed during melting. It occurred due to rapid melting of the material, since the arc furnace melts at high temperature very quickly, without sufficient time to dissociate $\mathrm{SiC}$ in melting of the masteralloy.

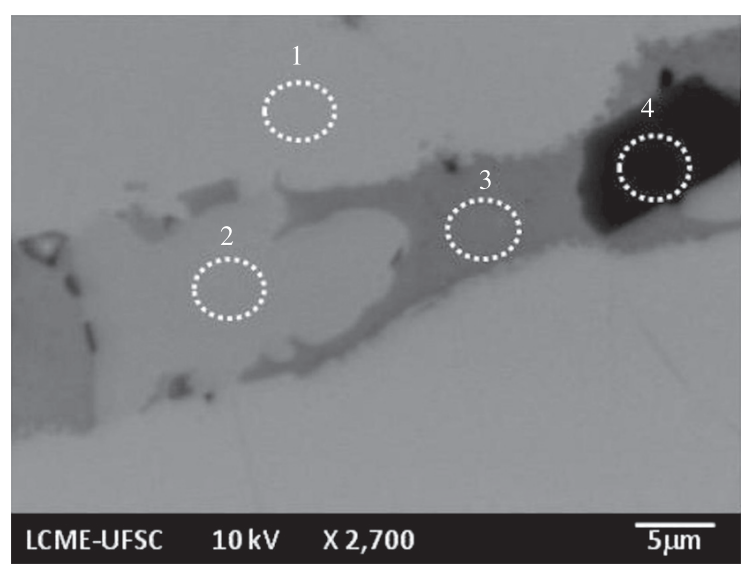

\begin{tabular}{ccccccc}
\hline & \multicolumn{6}{c}{ wt. $(\%)$} \\
\cline { 2 - 7 } & $\mathbf{C}$ & $\mathbf{O}$ & Si & Mn & Fe & Ni \\
\hline 1 & -- & 0.84 & 18.52 & 29.31 & 46.22 & 5.10 \\
2 & -- & 0.73 & 24.02 & 11.37 & 50.84 & 9.88 \\
3 & -- & 9.35 & 27.31 & 20.35 & 29.93 & 11.99 \\
4 & 50.3 & -- & 49.7 & -- & -- & --
\end{tabular}

Figure 3. SEM and EDS analyses in specific phases of the masteralloy.
A color map of the chemical elements present in the as-casted SMN1 sample is shown in Figure 5. The original image was obtained in the FEG electron microcope. Each chemical element is apparently concentrated in particular regions of the microstructure thus characterized by intense heterogeneity.

Analyzing the Figures 3, 4, 5 and 6, it can be identified the presence of $\mathrm{SiC}$ particles in the material. Figures 3 and 5 show other phases of SMN1 that contains simultaneously in its composition the elements $\mathrm{Si}, \mathrm{Ni}, \mathrm{Fe}$ and $\mathrm{Mn}$, however in different contents depending on the phase found. Thereby five distinct crystalline phases were observed (Fe2Si,

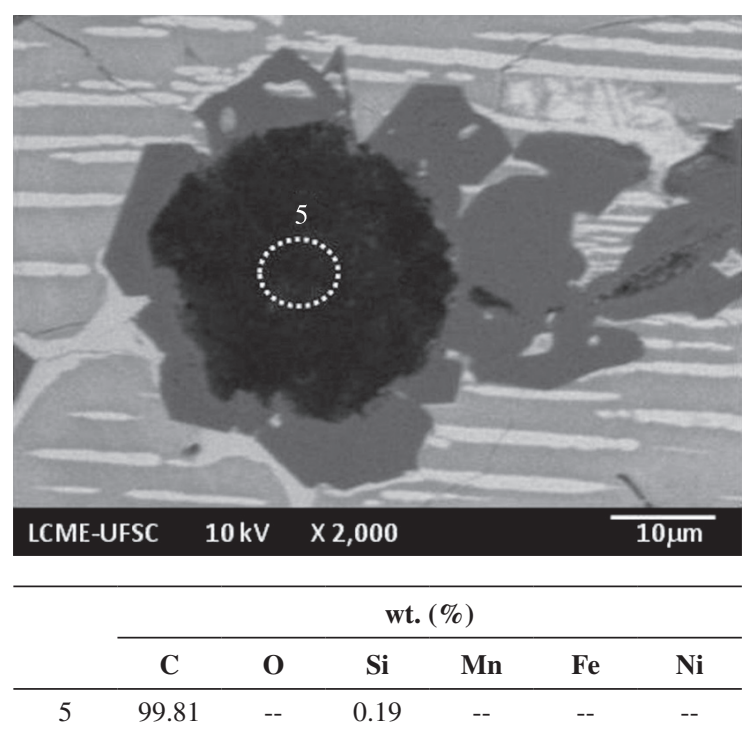

Figure 4. Detailed SEM and EDS analyses of the masteralloy.
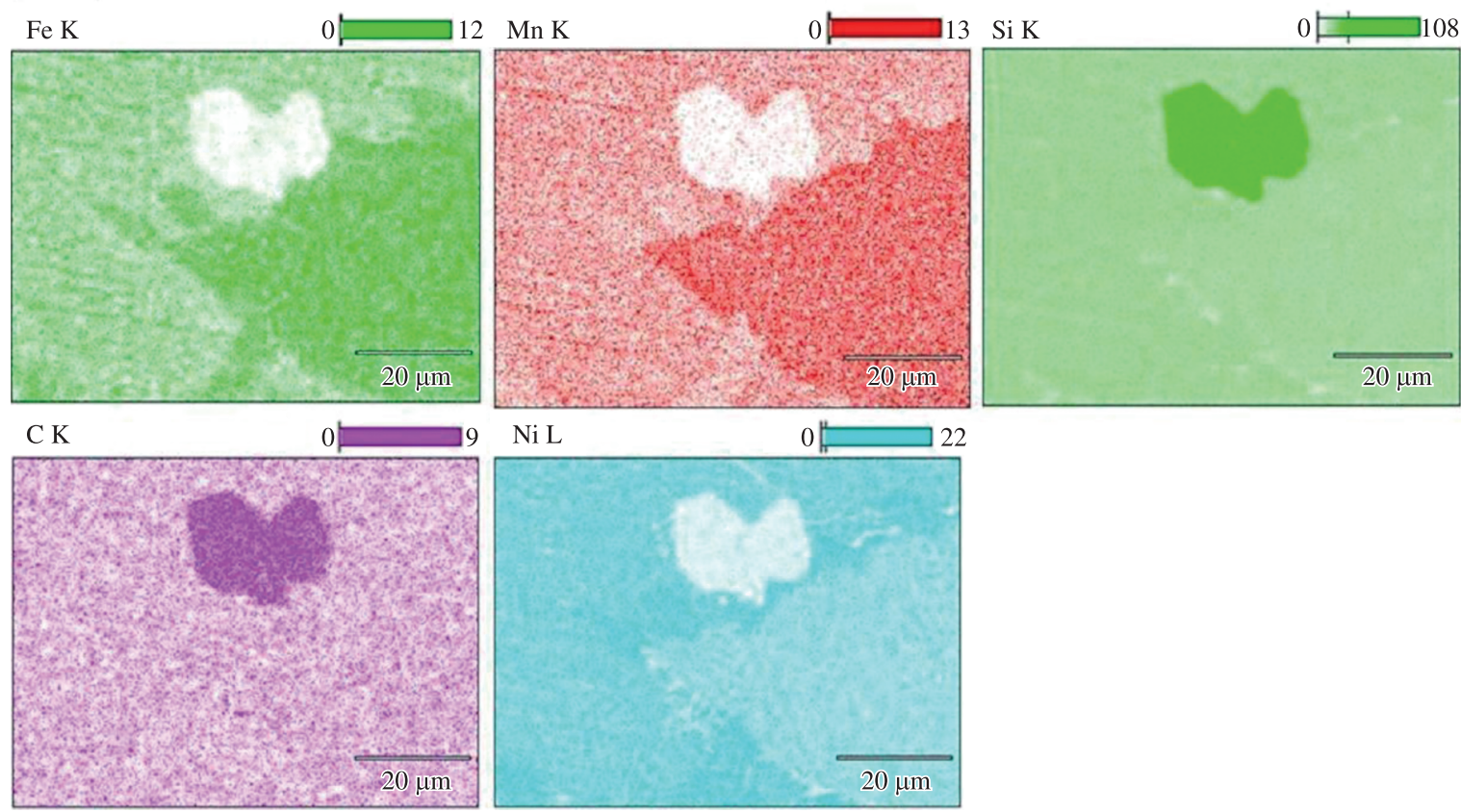

Figure 5. EDS colour map of the microstructure of the masteralloy. 


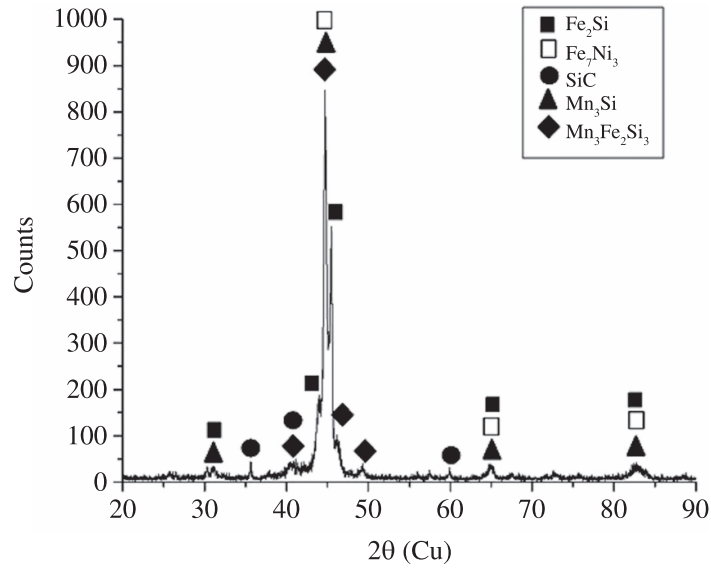

Figure 6. XRD pattern of SMN1 masteralloy.

$\mathrm{Fe} 7 \mathrm{Ni3}, \mathrm{SiC}, \mathrm{Mn} 3 \mathrm{Si}$ and $\mathrm{Mn} 3 \mathrm{Fe} 2 \mathrm{Si} 3$ ) in the XRD analysis of the as-casted SMN1 sample, as shown the Figure 6.

The results of Vickers microhardness indentation measurements undertaken on the masteralloy sample are shown in Figure 7. Regions 1, 2 and 3 presented similar microhardness values, around 1150 MHV50, in contrast with the relatively high microhardness of $\mathrm{SiC}$ particles (around 2500 MHV50).

Apparently, there are $\mathrm{SiC}$ particles remaining in the microstructure of the casted masteralloy. This means that the $\mathrm{SiC}$ particles mixed to the powder blends did not dissolve completely during melting of the masteralloy. Figure 8 clearly shows a typical inhomogeneous microstructural area where $\mathrm{SiC}$ particles can be seen distributed in preferential regions.

Since the presence of $\mathrm{SiC}$ particles is deleterious to the masteralloy, DTA analyses were carried out to study the possibility of their dissolution by re-melting. Figure $9 \mathrm{a}$ shows only an exothermic peak corresponding to the melting of the alloy. As it can be seen in Figure 9b, even after re-melting, residual $\mathrm{SiC}$ particles can be found. This means that the silicon carbide is not suitable for production of the masteralloy because it leads to embrittlement of the material besides being highly abrasive for uniaxial die compaction causing wear. The chemical element $\mathrm{Si}$ has to be introduced in the alloy by using ferrosilicon.

\subsection{Characterization of the powder additive of masteralloy}

The morphology of SMN1 powders obtained by milling of the casted masteralloy billet is shown in Figure 10a. Comparatively, an image of the Höganäs ASC 100.29 iron powder is shown in Figure 10b.

The Fe powder is predominantly rounded whereas the powder corresponding to SMN1 is flake-like and contains finer particles comparing to the Fe powder. The particle size distribution of milled SMN1 is shown in Figure 11. The masteralloy powder has a sharp distribution of sizes. The laser diffraction analysis showed $\mathrm{d} 90=30.7 \mu \mathrm{m}$ and $\mathrm{d} 50=16.42 \mu \mathrm{m}$.

\subsection{Sintered steels produced via Fe + masteralloy additive}

The green density of $\mathrm{Fe}$ sample is $7.07 \mathrm{~g} / \mathrm{cm}^{3}, \mathrm{Fe}+6 \%$ SMN1 and Fe $+12 \%$ SMN1 is 6.83 and $6.64 \mathrm{~g} / \mathrm{cm}^{3}$,

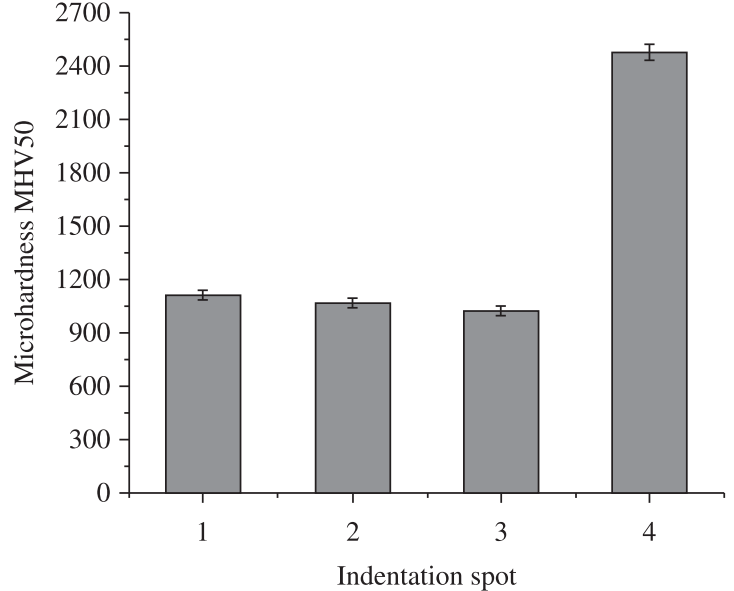

(a)

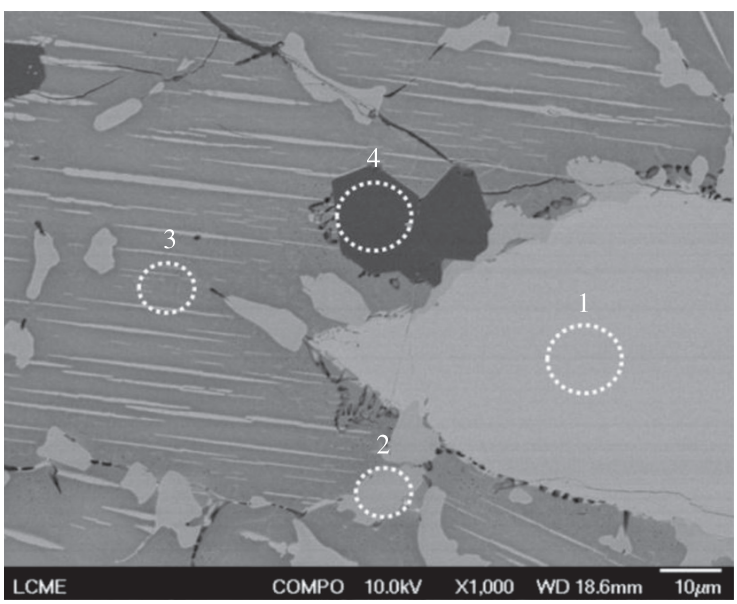

(b)

Figure 7. (a) Vickers microhardness of masteralloy and (b) indented regions.

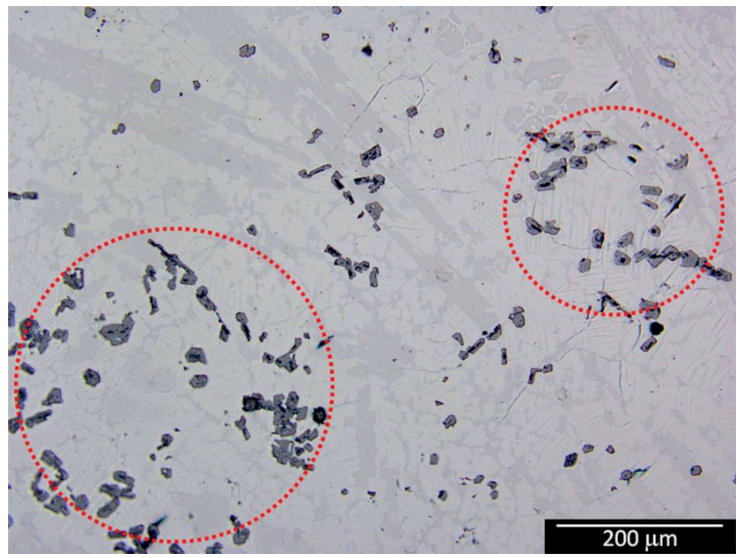

Figure 8. SiC particles in the microstructure of SMN1 after melting (not etched sample).

respectively. As expected, by increasing the amount of SMN1, the green density of the powder mixture decreased.

The dimensional variations of $\mathrm{Fe}$ and Fe-SMN1 compacts during heating up and isothermal sintering are 


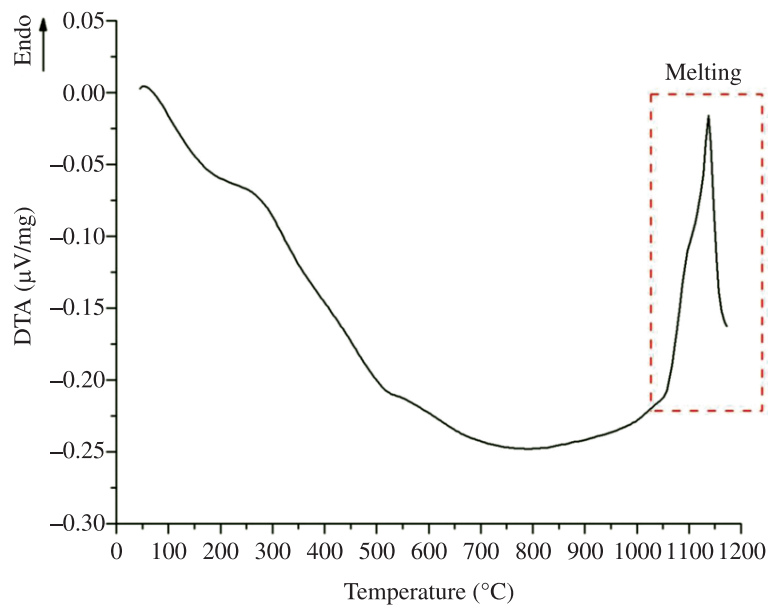

(a)

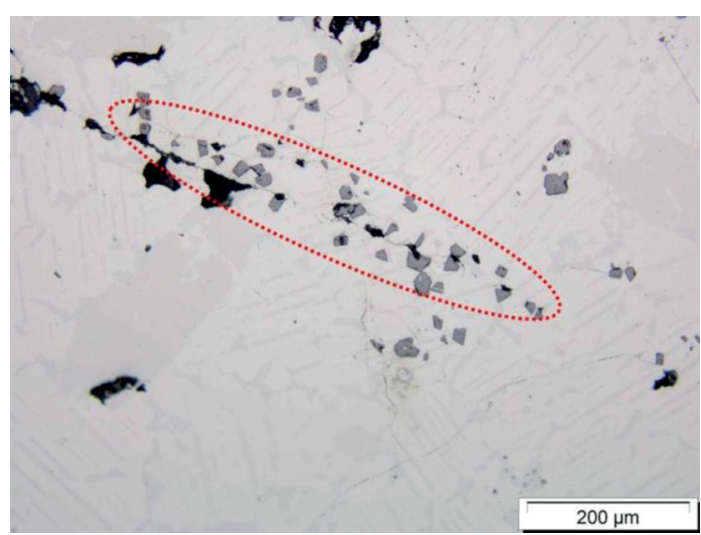

(b)

Figure 9. (a) DTA analysis of SMN1masteralloy. (b)Microstructure of SMN1 after DTA analysis (not etched sample).

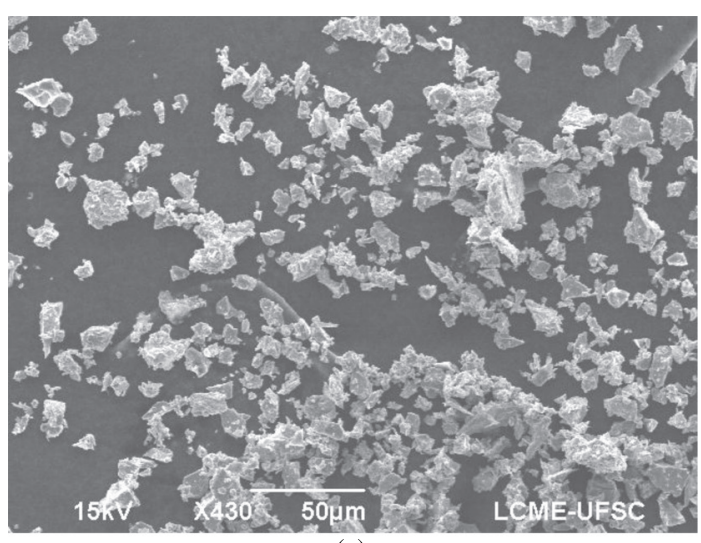

(a)

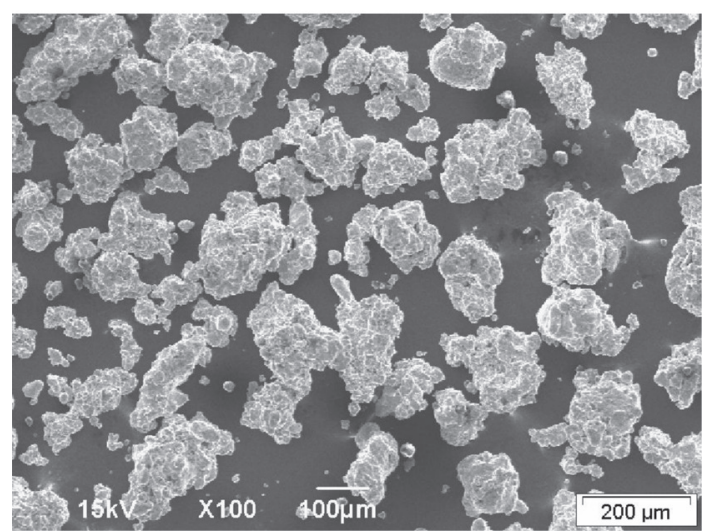

(b)

Figure 10. SEM image of powder morphology of (a) masteralloy powder after milling and (b) Fe.

shown in Figure 12. The shrinkage of the plain iron sample began at approximately $700{ }^{\circ} \mathrm{C}$, although part of this dimensional variation is normally a result of the reduction of oxide films eventually present on the iron particle surface, by reaction with the hydrogen present in the gas mixture. For the samples containing masteralloy additive, the ferrite

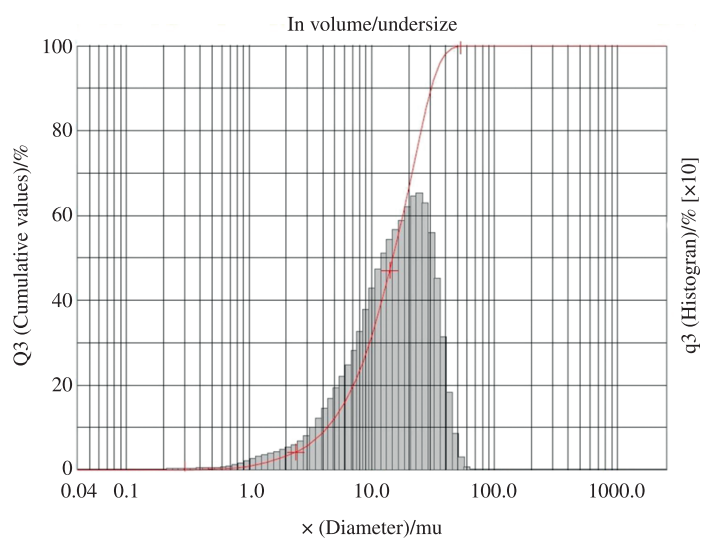

Figure 11. Particle size distribution of melted and milled masteralloy by diffraction laser analysis.

austenite transformation began at lower temperatures. This means that part of the volume of the iron particles transformed into austenite at lower temperatures, i.e., before transformation temperature of plain iron is reached, as a result of the enrichment of the outer region of iron particles with the alloying elements $\mathrm{Ni}$ and $\mathrm{Mn}$, which are -phase stabilizers. Carbon lowers the transformation temperature of iron and it diffuses quickly by interstitial diffusion ${ }^{24}$.

The sintered density of $\mathrm{Fe}, \mathrm{Fe}+6 \%$ SMN1 and $\mathrm{Fe}+12 \%$ SMN1 samples is $7.11,6.87$ and $6.66 \mathrm{~g} / \mathrm{cm}^{3}$, respectively. Theoretical density is $86.67 \%$ for $\mathrm{Fe}, 86.07 \%$ for $\mathrm{Fe}+6 \% \mathrm{SMN} 1$ and $83.87 \%$ for $\mathrm{Fe}+12 \% \mathrm{SMN} 1$.

The shrinkage of $\mathrm{Fe}+6 \% \mathrm{SMN} 1$ and $\mathrm{Fe}+12 \% \mathrm{SMN} 1$ compacts began at about $1150{ }^{\circ} \mathrm{C}$ where a transient liquid phase was gradually formed while residual masteralloy additive particles began to melt as shown the Figure 13 . The shrinkage rate remains intensive during the isothermal sintering stage. The transient liquid phase sintering accelerates the sintering process, which leads to improved mechanical properties ${ }^{14}$. As cited by Zhang et al. ${ }^{14}$, density and dimensional changes of $\mathrm{Fe}-\mathrm{Mn}$-Si masteralloy presented shrinkage for milled material when sintered in $\mathrm{H} 2$ or $\mathrm{Ar}-\mathrm{H} 2$ 
(5\%) atmosphere. On the other hand, for compacts made from the atomized masteralloy sintered in $\mathrm{H}_{2}$ and $\mathrm{Ar}-\mathrm{H} 2$ $(5 \%)$ showed swelling both in density and in length. The steel from atomized-milled masteralloy sintered in $\mathrm{H}_{2}$ demonstrated slight shrinkage in density and in length,

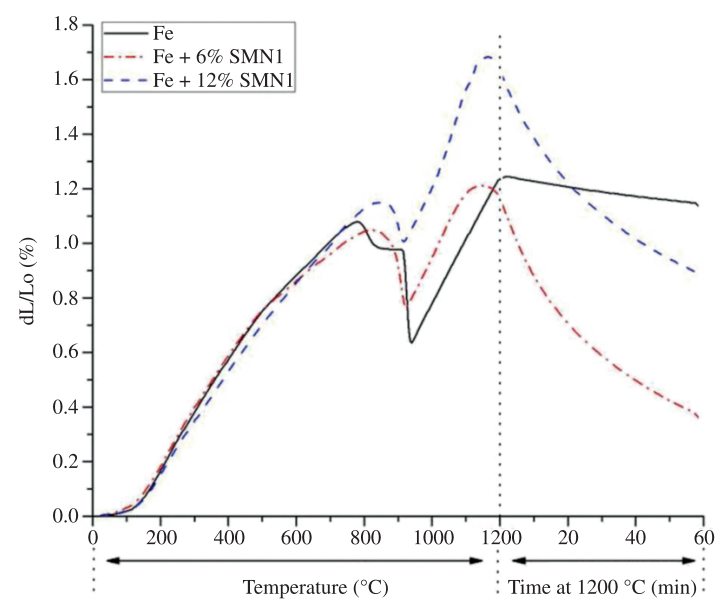

Figure 12. Dimensional variation during heating up and isothermal sintering of $\mathrm{Fe}$ (plain iron), $\mathrm{Fe}+6 \% \mathrm{SMN} 1$ and $\mathrm{Fe}+12 \% \mathrm{SMN} 1$ compacts.

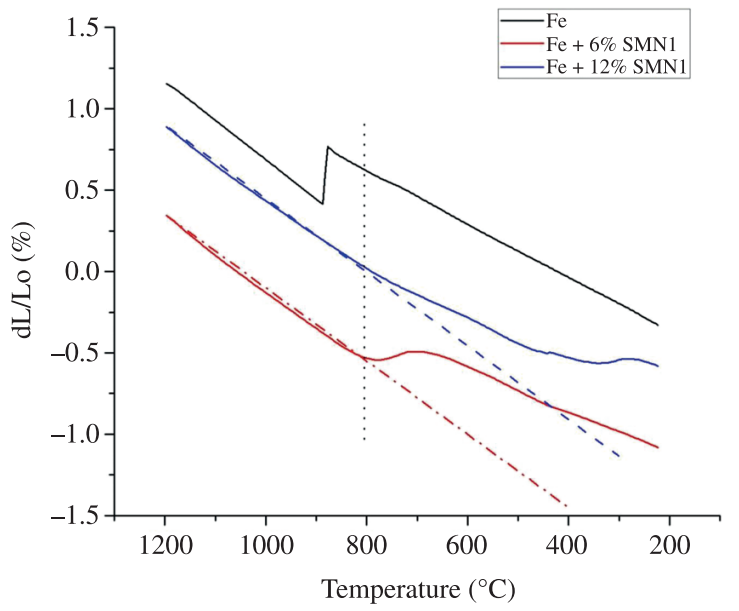

Figure 13. Dimensional changes during cooling for $\mathrm{Fe}, \mathrm{Fe}+6 \%$ SMN1 and Fe $+12 \%$ SMN1. while that sintered in $\mathrm{Ar}-\mathrm{H} 2(5 \%)$ shown slight swelling. All compacts sintered in $\mathrm{Ar}-\mathrm{H} 2(5 \%)$ shown lower density change and a larger dimensional change ${ }^{14}$.

As expected, the transformation in sintered plain iron began at approximately $912{ }^{\circ} \mathrm{C}$, whereas for the sintered steel containing $6 \% \mathrm{SMN} 1$ the transformation occurred approximately between 820 and $630{ }^{\circ} \mathrm{C}$. The fact that the transformation by cooling began only at approximately $820{ }^{\circ} \mathrm{C}$ suggested that even in the core of the largest iron particles, the chemical composition changed by homogenization during sintering. For the sintered steel with $12 \%$ SMN1, the transformation occurred in a range of even lower temperatures (approximately between $800{ }^{\circ} \mathrm{C}$ and $230{ }^{\circ} \mathrm{C}$ ). The delay in the transformation is caused by the austenite phase stabilization effect of $\mathrm{Ni}$ and $\mathrm{Mn}$ and it can be caused by carbon that is a strong gamma stabilizer and diffuses very fast. The transformation at such low temperatures is martensitic. As a result of the remaining chemical gradients along the volume of the samples, several phases can be formed during cooling. Part of the material, where the concentration of alloying elements is higher transforms into cubic martensite. This is typical in sintered steels with high concentrations of $\mathrm{Ni}$ and/or $\mathrm{Mn}^{1,13,25-27}$.

The microstructure of $\mathrm{Fe}, \mathrm{Fe}+6 \% \mathrm{SMN} 1$ and $\mathrm{Fe}+12 \%$ SMN1 after sintering is shown in Figure 14. Whereas the microstructure of the plain iron sample presents the cubic body centered -phase and residual porosity, the sintered steel containing $6 \%$ SMN1 additive depicted ferrite, perlite and residual porosity. On the other hand, the sintered steel containing $12 \%$ SMN1 consisted of ferrite, bainite, cubic martensite, and residual porosity.

The Vickers microhardness values of the sintered samples along with images of the indented areas are shown in Figure $15^{13-14}$. In the samples containing SMN1, hardness was accordingly higher. Measurements at point number 4, just in the centre of the former larger iron particles, where the phase encountered was ferrite, the hardness was higher than that of plain iron samples, proving that even at this point, the chemical composition changed by alloying. This was also observed by analyzing the temperature where the sintered steel initiated its transformation (approximately $760{ }^{\circ} \mathrm{C}$ instead of $912{ }^{\circ} \mathrm{C}$ ). No residual $\mathrm{SiC}$ or graphite nodules were observed in the sintered steels, despite the presence of $\mathrm{SiC}$ particles in the masteralloy additive used to produce the sintered steels.

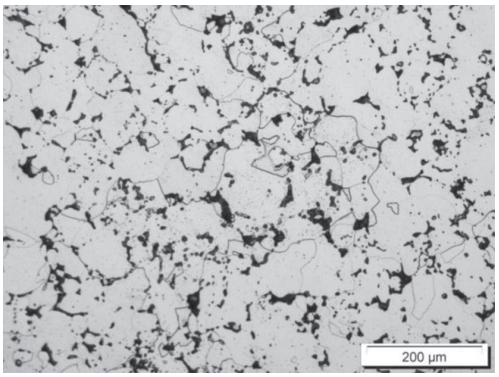

(a)

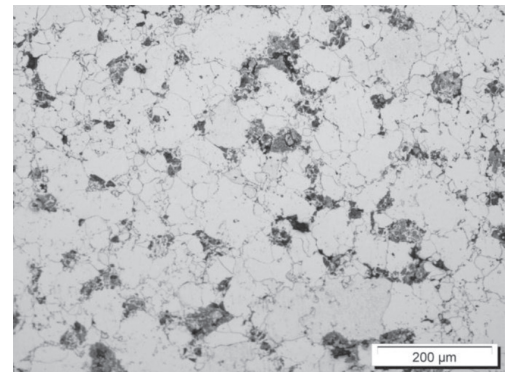

(b)

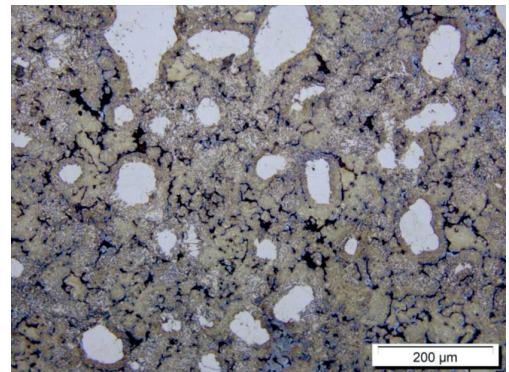

(c)

Figure 14. Microstructure of (a) Fe, (b) $\mathrm{Fe}+6 \% \mathrm{SMN} 1$ and (c) $\mathrm{Fe}+12 \% \mathrm{SMN} 1$ after sintering. 

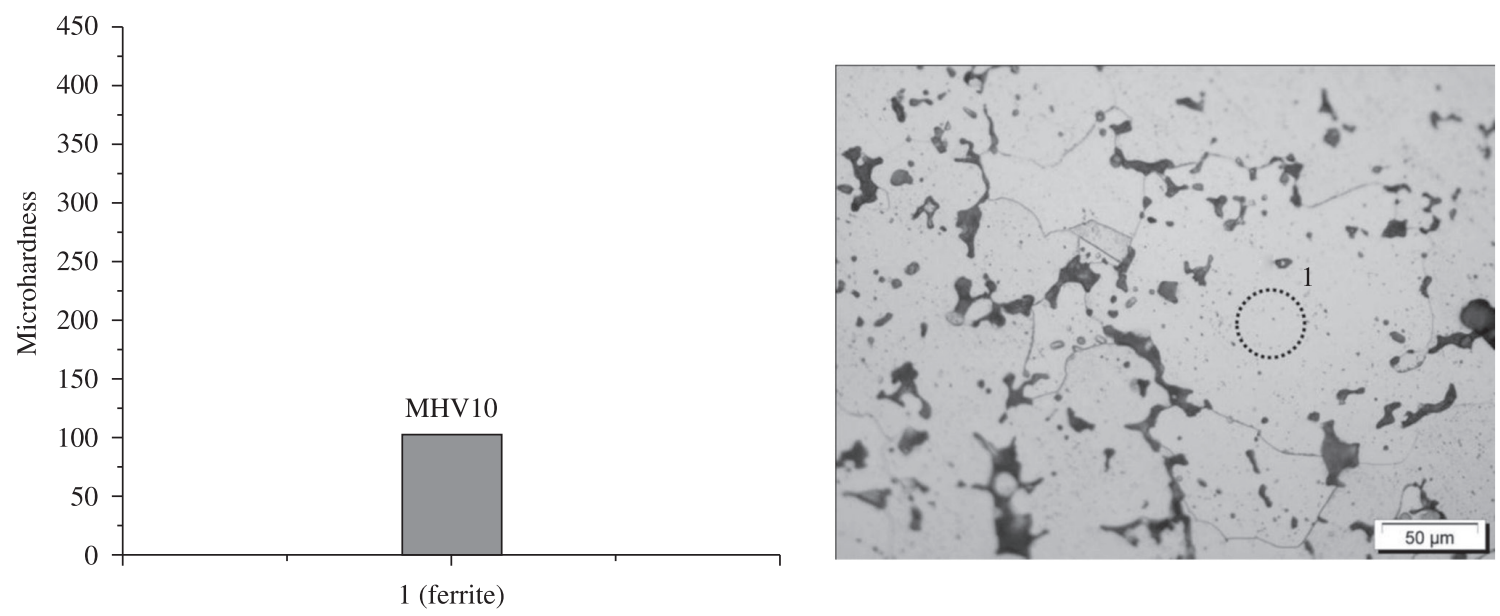

(a)
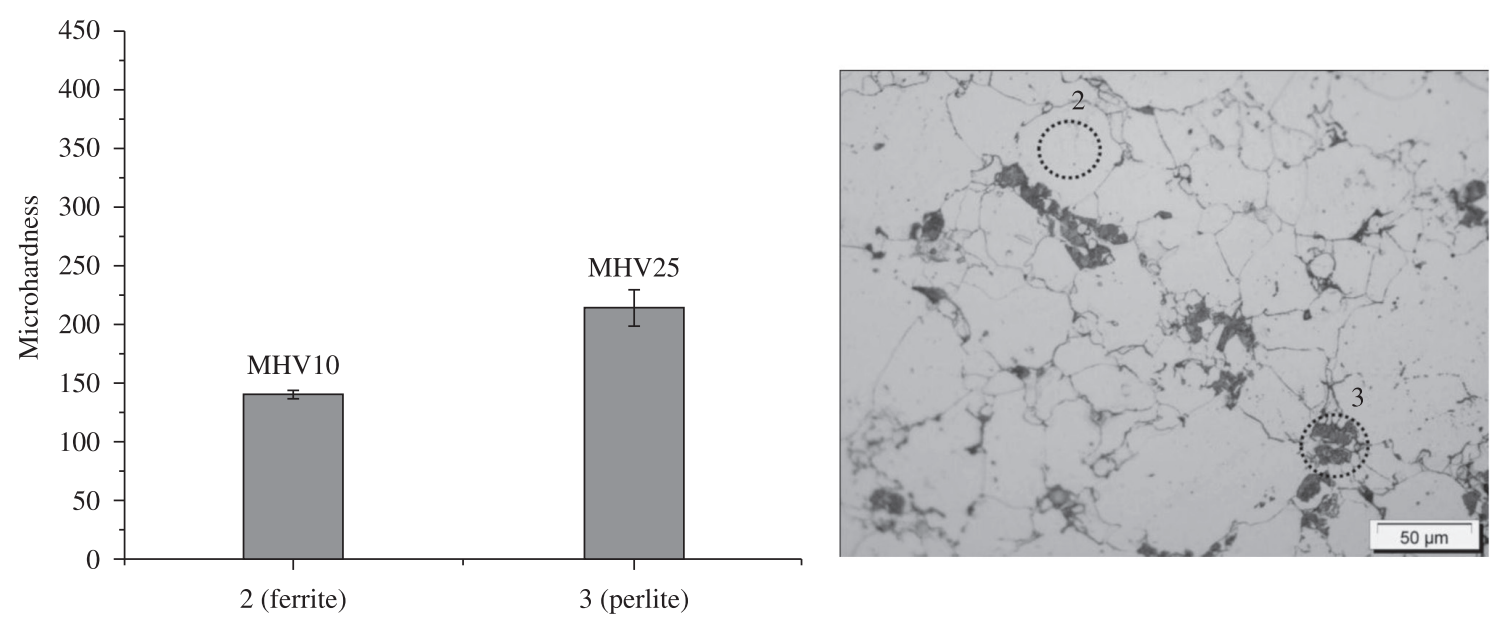

(b)
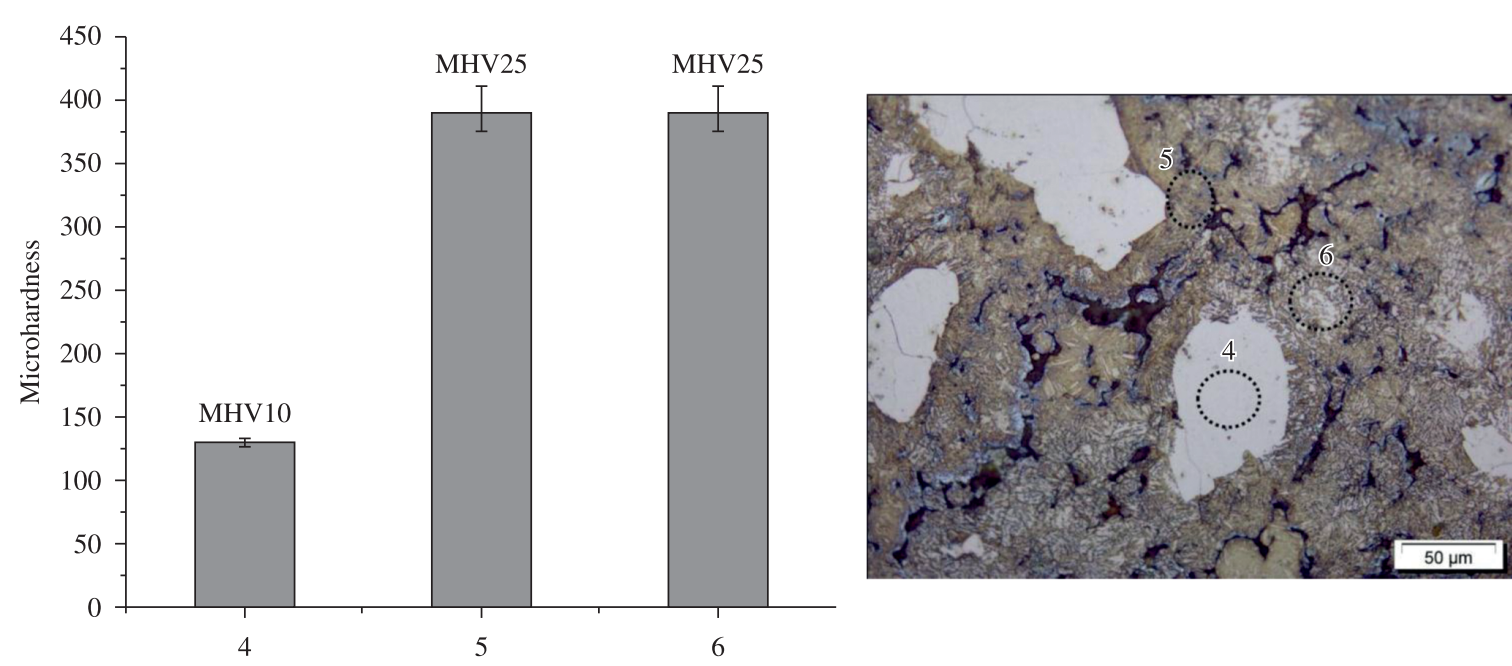

(c)

Figure 15. Microhardness and indented regions of (a) Fe, (b) Fe $+6 \%$ SMN1 and (c) Fe $+12 \%$ SMN1 sintered samples. 


\section{Conclusions}

The casted billet obtained by melting the masteralloy was easily crushed and milled because of the presence of defects such as cracks and the fragile characteristic of the microstructure (called SMN1) with 5 distinct phases; SiC used in the powder mixture was not fully dissolved during the casting process. Remaining SiC particles were found on the cast billet. The masteralloy should even be improved by changing $\mathrm{SiC}$ by ferrosilicon because it is difficult to dissolve $\mathrm{SiC}$ under the conditions (temperature and time) used to melt the masteralloy.

\section{References}

1. Klein AN, Oberacker R and Thummler F. Development of new high strength sintered steels containing silicon and manganese. Metal Powder Report. 1984; 39(6):335-338.

2. Klein AN, Salcedo RA and Arroyo IK. Aços sinterizados de elevada resistência, contendo Nb, Mo, Mn e Si. In: Proceedings of the 7th Cbecimat; 1986; Florianópolis. Florianópolis; 1986. p. 351-355

3. Klein AN. Untersuchungen zur herstellung und eigenschften neuartiger Si-Mn legierter sinterstaele. [Thesis]. Karlsruhe University; 1983.

4. Bier W, Dariel MP, Frage N, Hartmann S and Michailov O. Die compaction of copper powder designed for material parameter identification. International Journal of Mechanical Sciences. 2007; 49(6):766-777. http://dx.doi.org/10.1016/j. ijmecsci.2006.09.026

5. Al-Qureshi HA, Galiotto A and Klein AN. On the mechanics of cold die compaction for powder metallurgy. Journal of Materials Processing Technology. 2005; 166(1):135-143. http://dx.doi.org/10.1016/j.jmatprotec.2004.08.009

6. Li Y, Li L and Khalil KA. Effect of powder loading on metal injection molding stainless steels. Journal of Materials Processing Technology. 2007; 183:432-439. http://dx.doi. org/10.1016/j.jmatprotec.2006.10.039

7. Wu Y, German RM, Blaine D, Marx B and Schlaeffer C. Effects of residual carbon content on sintering shrinkage, microstructure and mechanical properties of injection molded 17-4 PH stainless steel. Journal of Materials Science. 2002; 37(17):3573-3583. http://dx.doi.org/10.1023/A:1016532418920

8. Wu Y, Blaine D, Marx B, Schlaefer C and German RM. Sintering densification and microstructural evolution of injection molding grade 17-4 PH stainless steel powder. Metallurgical and Materials Transactions A. 2002; 33(A):2185-2194.

9. Liang W, Ze-bao L and Hong-pei S. Properties and forming process of prealloyed powder metallurgy Ti-6Al4V alloy. Transactions of Nonferrous Metals Society of China. 2007; 17:s639-s643.

10. Dlapka $\mathrm{M}$, Danninger $\mathrm{H}$, Gierl $\mathrm{C}$ and Lindqvist B. Sinterhärten - eine spezielle Wärmebehandlung für pulvermetallurgische Präzisionsteile. Journal of Heat Treatment and Materials. 2012; 67(3):223-231.

11. Oro R, Campos M, Hryha E, Nyborg L and Torralba JM. Surface analysis at different sitnering stages of steel compacts with Mn and Si. In: Euro Powder Metallurgy; 2011; Barcelona. Shewsbury SY1 1LG, UK; 2011. p. 113-118.

12. Thummler F, Klein AN and Oberacker R. Method for powder metallurgical production of structural parts of great strength and hardness from Si-Mn or Si-Mn-C alloyed steels. U.S. Patent No. 4.913.739; 1990.

13. Klein AN, Oberacker R and Thummler F. High strength Si-Mn-Alloyed sintered steels. Powder Metallurgy International. 1985; 17(1):13-16.
The sintered steels produced using the SMN1 masteralloy to alloy the iron matrix, even by normal cooling from the sintering temperature, present a microstructure consisting of ferrite, perlite, bainite and cubic martensite), as a consequence of the heterogeneity of the chemical composition which introduced variable hardenability along the volume of the sample.

\section{Acknowledgments}

The authors thank CNPq for its financial support and LCME-UFSC for providing the microscopic analyses carried out in this work.

14. Zhang $\mathrm{Z}$ and Sandstrom R. Fe-Mn-Si master alloy steel by powder metallurgy processing. Journal of Alloys and Compounds. 2004; 363:194-202. http://dx.doi.org/10.1016/ S0925-8388(03)00462-6

15. Klein AN, Oberacker R and Thummler F. Development of new high strength Si-Mn-alloyed sintered steels. Modern Developments in Powder Metallurgy. 1985; 15-17:141-152.

16. Banerjee S, Schlieper G, Thümmler F and Zapf G. New results in the master alloy concept fot high strength sintered steels. Modern Developments in Powder Metallurgy. 1981; 13:143-157.

17. Schlieper G. Report Kernforschungszentrum Karlruhe. [Thesis]. Karlruhe University Kfk; 1979.

18. Hamiuddin Md and Upadhyaya GS. Effect of transition metal carbides master alloy MCM on sintering of iron Fe-P powder premix. Powder Metallurgy International. 1980; 12(2):65-69.

19. Banerjee S, Gemenetzis V and Thümmler F. Effect of nickel on sintering of $\mathrm{P}$ containing iron. Powder Metallurgy. 1980; 23(3):126-129.

20. Furukimi O, Maruta K, Abe T, Takajo S and Habu Y. Partially prealloyed steel powder containing nickel and molybdenum for ultra strength sintered materials. Powder Metalurgy. 1991; 34(3):212-214.

21. Lindskog $\mathbf{P}$ and Thornblad O. Ways to improve the strength of sintered components made from partially pre-alloyed steel powders. Powder Metallurgy International. 1979; 11(1):10-11.

22. Khaleghi M and Haynes R. Sintering and heat treatment of steels made from a partially prealloyed iron powder. Powder Metallurgy International. 1985; 28(4):217-223.

23. Sonsino CM and Schlieper G. Improvement of mechanical properties of diffusion and prealloyed sintered steels by heat treatments. Powder Metallurgy International. 1992; 24(6):339-344.

24. Klein AN, Klausmann R, Oberacker R and Thummler F. Relevance of liquid phases in sintering of high strength PM-steels. In: Proceedings of the Sintering theory and practice; 1984; London. London; 1984. p. 1-10.

25. Marquardt A, Recknagel C, Langer I, Müller S and Kieback B. Improved mechanical properties of low alloyed sintered steels through Fe-Mn-Si master alloys. In: Proceedings of the Euro Powder Metallurgy Conference; 2011; Barcelona. Shewsbury SY1 1LG, UK; 2011. p. 107-112.

26. Salak A and Selecka M. Metals. In: Manganese in Powder Metallurgy Steels. Cambridge International Science Publishing, Elsevier; 2012. p. 1-475. http://dx.doi.org/10.1007/978-1907343-75-9

27. Danninger H, Pöttschacher R, Bradac S, Salak A and Seyrkammer J. Comparison of $\mathrm{Mn}, \mathrm{Cr}$ and Mo alloyed sintered steels prepared from elemental powders. Powder Metallurgy. 2005; 48(1):23-32. http://dx.doi. org/10.1179/003258905X37567 